\title{
ELEMENTAL COMPOSITON OF SOME SOILS IN CENTRAL PART OF BOSNIA AND HERZEGOVINA IN RELATION TO SOIL TYPE, REGION AND LAND USE
}

\author{
Elementarni sastav nekih tala središnjeg dijela \\ Bosne i Hercegovine u odnosu na tip tla, područje istraživanja i način korištenja
}

\author{
Emira Hukić $^{1}$, Mirza Tvica ${ }^{2}$
}

\begin{abstract}
Elemental composition of the surface soil layers has a direct effect on soil productivity and an important role in the quality of the terrestrial ecosystems. Herein, soil has the function of a geochemical sink and natural buffer, controlling the release of contaminants to hydrosphere, atmosphere, and biota. Vertical distribution of $\mathrm{HNO}_{3}$ pressure digested concentrations of $\mathrm{Na}, \mathrm{K}, \mathrm{Ca}, \mathrm{Mg}, \mathrm{Fe}, \mathrm{Al}, \mathrm{Mn}, \mathrm{P}, \mathrm{S}, \mathrm{Cd}, \mathrm{Co}, \mathrm{Cu}, \mathrm{Cr}, \mathrm{Ni}$, $\mathrm{Pb}, \mathrm{Zn}$ is determined in three rather common soil types: Cambisol, Dystric, Cambisol, Eutric and Fluvisol in central part of Bosnia and Herzegovina. Site differences, with the reference to soil parent material, dominantly influenced element distribution and accumulation. In addition to land-use, forest seedling production influenced significant $(p<0.05)$ decrease of $\mathrm{Ca}$ in Ajdinovići, $\mathrm{Mg}$ in Žepče and $\mathrm{S}$ in all three sites in 0 to $30 \mathrm{~cm}$ soil depth. Summary data for element concentrations for this central region, reported with medians, were: $0.76 \mathrm{~g} / \mathrm{kg} \mathrm{Na}, 9.30 \mathrm{~g} / \mathrm{kg} \mathrm{K}, 3.54 \mathrm{~g} / \mathrm{kg} \mathrm{Ca}, 5.28 \mathrm{~g} / \mathrm{kg} \mathrm{Mg}, 27.9 \mathrm{~g} / \mathrm{kg}$ Fe, 43.7 g/kg Al. 0,98 g/kg Mn, 0.5 g/kg P, 0.27 g/kg S, 3.46 mg/kg Cd, 18.4 mg/kg Co, $99.5 \mathrm{mg} / \mathrm{kg}, 24.7 \mathrm{mg} / \mathrm{kg} \mathrm{Cu}, 65.1 \mathrm{mg} / \mathrm{kg} \mathrm{Ni}, 30.6 \mathrm{mg} / \mathrm{kg} \mathrm{Pb}, 90.7 \mathrm{mg} / \mathrm{kg} \mathrm{Zn}$.
\end{abstract}

Key words: Elementaty composition, macro-elements, micro-elements, Bosnia and Herzegovina, soil type, land use

\section{INTRODUCTION - Uvod}

The abundance of macro-and micro-elements in surface and subsurface soil layers is primarily the result of geological and pedological factors (SHACKLETTE \& Boergen, 1984, KabatA-Pendias \& Pendias, 2001), although in the environmental matters, accumulation and distribution of some element in soil can be related to different anthropogenic activities (ADRIANO, 1986).

Elemental composition in the surface soil layers directly influence soil productivity, as some elements are important plant nutrients. Thus, according to their

\footnotetext{
${ }^{1}$ Faculty of forestry, University of Sarajevo

${ }^{2}$ Faculty of Aagriculture and food sceince, University of Sarajevo
} 
essentiality nitrogen $(\mathrm{N})$, phosphorous $(\mathrm{P})$ and potassium $(\mathrm{K})$ are primary nutrients, calcium $(\mathrm{Ca})$, magnesium $(\mathrm{Mg})$ and sulfur $(\mathrm{S})$ are secondary and elements such as iron $(\mathrm{Fe})$, manganese $(\mathrm{Mn})$, zinc $(\mathrm{Zn})$, cooper $(\mathrm{Cu})$ and some others, are considered as micro-nutrients (PRASAD \& POWER, 1997). In substantial amounts micro-nutrients, are toxic and represent growing concern for ecological, evolutionary, nutritional and environmental reasons (BENAVIDES ET AL., 2005). Therefore, element stocks and their cycles are important not only for the soil quality evaluations, but also for understanding the quality of the terrestrial environments in our country.

The type of soil analysis, used for assessments of the accumulated pollution, implies extraction procedures with strong acids and Aqua Regia, where extracted element concentrations are recognized as pseudo-total or non-silicate ones (URE, 1996). These pseudo-total amounts are commonly considered as total amounts in soil analysis, although certain amounts of elements can be held in silicate bonds. Elements concentrations do not have to be in the available forms in soil and generally their extractability in soil has chemical gradient with soil depth, mainly controlled by the soil $\mathrm{pH}$, redox conditions, along with course of weathering, water regime, organic mater content, cation exchange capacity, clay content, nutrient content and concentration of other elements (ĆIRIĆ, 1986, KABATA-PENDIAS \& PENDIAS, 2001).

Most geochemical investigations of soil and other surface materials in the world are conducted with a purpose of establishing normal element concentrations or background levels of elements, by which anomalous concentrations, both natural and anthropogenicly induced, could be judged (SHACKLETTE \& BOERNGEN, 1984, YANAI ET AL., 2012).

So far, reports on element composition of soils and other surface materials in Bosnia and Herzegovina are mostly related to economically approved purposes such as mineral mining, hydrogeological purposes and sporadically heavy metals pollution of agricultural soils (GOLETIĆ, 1999, IVETIĆ ET AL., 1987), or the once of the industrial and urban areas (IVETIĆ, 1987). Whereas, accumulation and vertical distribution of macro- and micro-elements in relation to soil type, region and land-use, in our country, are readily reported and insufficiently investigated.

Therefore the objective of this study was 1) to detect vertical distribution of macro- and micro-elements in soil profiles with the reference to the soil type, 2) to investigate relationship among element concentrations, land use and site specifics of one region in surface layers and 3) to evaluate approximate element contents in surface soil layers in central part of Bosnia and Herzegovina.

\section{MATERIAL AND METHODS - Materijal i metode}

\section{Study site description and soil sampling - Opis istraživanog područja $i$ načina uzimanja uzoraka tla}

Table 1 shows characteristics of all three investigated sites. Reported soil types were taken from the Soil Map of SFRY, classified by WRB system, and 
according to land-use they were attributed as natural soils used as meadows and cultivated soils used for forest seedlings production.

Ajdinovići study site is an upland area in southwestern part of "the Ophiolitic zone of Bosnia and Herzegovina" (PETKOVIĆ, 1961) covered with an acid colluvium (TOKIĆ, 1983), laying over Triassic limestone (STRAJIN ET AL., 1978). In broader Ajdinovići area, which is rather isolated from industrial influences, high concentrations of some micro-elements were reported in soils (RAMOVIĆ, 1984). Substantial amounts of $\mathrm{Pb}, \mathrm{Mn}$ and $\mathrm{Fe}$ were found in this area, which are considered to be in relation to weathering products of cerusite $\left(\mathrm{PbCO}_{3}\right)$ strings and galenit $(\mathrm{PbS})$ of the bedrock material (RAMOVIĆ, 1984).

Two other sites are alluviums of rivers "Bosna" and "Kozica" in the urban zones of Žepče and Busovača. The first site belongs also to "the Ophiolitic zone" with typical ultramafic rocks such as peridotites and serpentinised peridotites, surrounding studied alluvium which lays over Pleistocene overburdens (SUNARIĆ-PAMIĆ ET AL., 1966).

Parent material in Busovača is very interesting for it geological age of Silur and Devon. Paleozoic shale parent material present in Busovača is alluvial-glacial overburden whit domination of minerals such as chlorate-muscovite, quartz-sericite, sericite shales, tourmaline, zircon, hematite and limonite (ŽIVANOVIĆ ET AL., 1967).

Table 1. Main description data of the investigated sites

Tabela 1. Bitna prirodna obilježja istraživanog područja

\begin{tabular}{lrrr}
\hline Site specifics & Ajdinovići & Žepče & Busovača \\
Average temperatures in ${ }^{\circ} \mathrm{C}^{1}$ & 7,6 & 11,2 & 8,4 \\
Average precipitation in $\mathrm{mm}^{1}$ & 926,5 & 838,6 & 848,4 \\
Altitude & $\sim 850 \mathrm{~m}$ & $\sim 235 \mathrm{~m}$ & $\sim 385 \mathrm{~m}$ \\
& silicate & silicate & silicate fluvioglacial \\
Parent material ${ }^{2}$ & colluviums & alluvium & sediments \\
Soil type & Cambisol & Fluvisol & Fluvisol \\
Nb. of soil samples in profile & 7 & 12 & 12 \\
Nb. of composite soil samples & 20 & 20 & 24 \\
\hline eral hydrometeorogical institute of Bosnia and Herzegovina & & \\
logical Map of SFRY in scale 1:100 000 & &
\end{tabular}

Ninety five samples were used, which were collected from twelve soil profiles ( 3 profiles of natural soil and 7 of cultivated soil) and surface area (64 samples) of approximately $25 \times 20 \mathrm{~m}^{2}$ using augers, from the three study sites. Every representative sample represents multiple samples created by the homogenization of approximately 50 soil partitions from the depths of 0 to $10 \mathrm{~cm}$ and 10 to $30 \mathrm{~cm}$. Samples were dried over night at $40{ }^{\circ} \mathrm{C}$, mild and sieved through the $2 \mathrm{~mm}$ sieve. 


\section{Field methods - Terenske metode istraživanja}

Twelve soil profiles were described using FAO field guide (2006) and classified according to WRB system (IUSS WORKING GROUP WRB, 2006).

\section{Analytic methods - Laboratorijske metode istraživanja}

In this study pseudo-total (non-silicate) concentrations (URE, 1996) were determined for sixteen soil elements: aluminum $(\mathrm{Al})$, iron $(\mathrm{Fe})$, potassium $(\mathrm{K})$, sodium $(\mathrm{Na})$, calcium $(\mathrm{Ca})$, magnesium $(\mathrm{Mg})$, phosphorous $(\mathrm{P})$, sulfur $(\mathrm{S})$, manganese $(\mathrm{Mn})$ and trace-elements cadmium $(\mathrm{Cd})$, copper $(\mathrm{Cu})$, chromium $(\mathrm{Cr})$, cobalt $(\mathrm{Co})$, nickel $(\mathrm{Ni})$, lead $(\mathrm{Pb})$ and zinc $(\mathrm{Zn})$. These are selected to cover most of the essential nutrients along with some of the soil micro-elements regard as potentially toxic in substantial amounts.

Extraction was made with a $100 \mathrm{mg}$ of finely ground $(<180 \mu \mathrm{m})$ soil sample with a concentrated $\mathrm{HNO}_{3}$ mixed in Teflon beakers and heated on $180^{\circ} \mathrm{C}$ over night. After it was cooled down, $10 \mathrm{ml}$ of distilled water was given in to bakers to achieve $\mathrm{NO}_{2}$ evolvement. The solution was filtrated to a $50 \mathrm{ml}$ flask, later filed up with distilled water up to the mark. Silicate rest on the filter paper was determined after burning for two hours on $500{ }^{\circ} \mathrm{C}$. The concentrations of all elements were determined in prepared solution by inductively coupled plasma optic emission spectrophotometer (Spectro ciros, ICP-OES).

Other analyzed soil properties were soil texture determined by using pipette- $\mathrm{B}$ method dispersed with $\mathrm{Na}_{2} \mathrm{P}_{4} \mathrm{O}_{7} \times 10 \mathrm{H}_{2} \mathrm{O}$, soil $\mathrm{pH}$ values measured in suspension of soil and extraction regent $0.01 \mathrm{M} \mathrm{CaCl}_{2}$ of $1: 2.5$ and total amount of organic $\mathrm{C}$ by dry combustion method on Element Analyzer (Heraeus vario EL.)

\section{Statistical analysis - Statističke metode istraživanja}

Descriptive statistics were calculated for the overall dataset of 16 elements in soils in central part of $\mathrm{B} \& \mathrm{H}$, for every studied site and two aspects of a land-use at the depths of 0 to 10 and 10 to $30 \mathrm{~cm}$. Kruskal-Wallis, Mann Whitney- $U$ and Kolmogorov-Smirnov $Z$ test were conducted to test the differences in element concentrations among all three sites and different land-use.

\section{RESULTS AND DISCUSSION - Rezultati i rasprava}

\section{Soil classification - Klasifikacija tla}

Investigated soils, during field observations, were classified according to WRB classification system (IUSS WRB WORKING GROUP, 2006) as Cambisol (Dystric, Colluvic) in Ajdinovići, Cambisols (Eutric) in Žepče and Fluvisol in Busovača. Soils cultivated for forest seedlings production were attributed with the suffix "Anthric" with a typical "Ap" 
horizon approximately $30 \mathrm{~cm}$ thick that is the result of long-term ploughing and fertilization. Relevant soil properties: texture, $\mathrm{pH}$ values and total organic carbon (C) are given in Table 2 along with element concentrations.

Elemental composition of natural and cultivated soils in relation to soil type - Elementarni sastav prirodnog $i$ antropogeniziranog tla u odnosu na tip tla

Table 2 shows the vertical distribution of element concentrations in different soil types of natural and corresponding cultivated soils at three different sites.

Concentrations of $\mathrm{P}$ and $\mathrm{S}$ were the highest in surface horizons in every investigated soil profile and further the highest amounts are noticed at a high altitude site Ajdinovići, which is explained as the result of larger organic partition in the total $\mathrm{HNO}_{3}$ extractable concentrations of these elements (BRADY, 1990). Potassium was mainly increasing with the increase of the soil depth and $\mathrm{Na}, \mathrm{Ca}, \mathrm{Mg}$ and $\mathrm{Mn}$ had no specific distribution trends whatsoever. Iron and $\mathrm{Al}$ were increasing with the depth and $\mathrm{Cd}, \mathrm{Co}$, $\mathrm{Cr}, \mathrm{Cu}, \mathrm{Ni}, \mathrm{Pb}$ and $\mathrm{Zn}$ were approximately equally distributed in the soil profile or they increased with the depth. Increase of some micro-elements with the increase of the depth is found to be strongly dependent on increase of fine granulometric fraction (KABATAPendias \& KRAKOVIAK, 1998). According to LeE ET AL. (1997) strong relationship between fine fraction and micro-elements could explain higher amounts of $\mathrm{Cd}, \mathrm{Co}, \mathrm{Ni}$, $\mathrm{Pb}$ and $\mathrm{Zn}$ in $\mathrm{B}$ horizon. Although, translocation and accumulation of different elements in soil profile are controlled by other soil properties, which alter in time and space (KABATA-PENDIAS \& KRAKOVIAK, 1998). In contrast, in soils derived from heterogenic parent materials, effects of pedogenetic processes on micro-elements distribution do not have to appear (SIDDIQUI \& KHATTAK, 2012).

Presence of potentially toxic concentrations, assigned by the Law on Agricultural Land of $\mathrm{B} \& \mathrm{H}$, is found in $\mathrm{Cd}$ concentrations at all three investigated sites. According to the Law, $\mathrm{Pb}$ and $\mathrm{Zn}$ in Ajdinovići and $\mathrm{Ni}$ and $\mathrm{Cr}$ in Žepče were rather high and also exceeding toxic values. Vertical distribution of these microelements, on the profile scale, suggests their possible geological origin, judged by other reports on presence of high concentrations of $\mathrm{Pb}, \mathrm{Zn}$ and $\mathrm{Mn}$ in Ajdinovići and $\mathrm{Cr}$ and Ni in Žepče.

\section{Elemental composition of soil in relation to region - Elementarni sastav tla u odnosu na područje istraživanja}

Studied site had a significant $(p<0.05)$ effect on the element concentrations except for $\mathrm{Fe}$ and $\mathrm{Cu}$, reflecting geochemical characteristics of the parent material and the degree of weathering (Table 3). Soils in Ajdinovići had the lowest concentrations of $\mathrm{Ca}(Z=2.192, p<0.05, Z=2.044, p<0.05)$ and the highest concentrations of $\mathrm{Al}$ $(Z=3.628, p<0.01, Z=1.978, p<0.05)$ and $\mathrm{S}(Z=1.814, p<0.05, Z=1.912, p<0.05)$, compare to the 0 to $30 \mathrm{~cm}$ depth in Žepče and Busovača. 


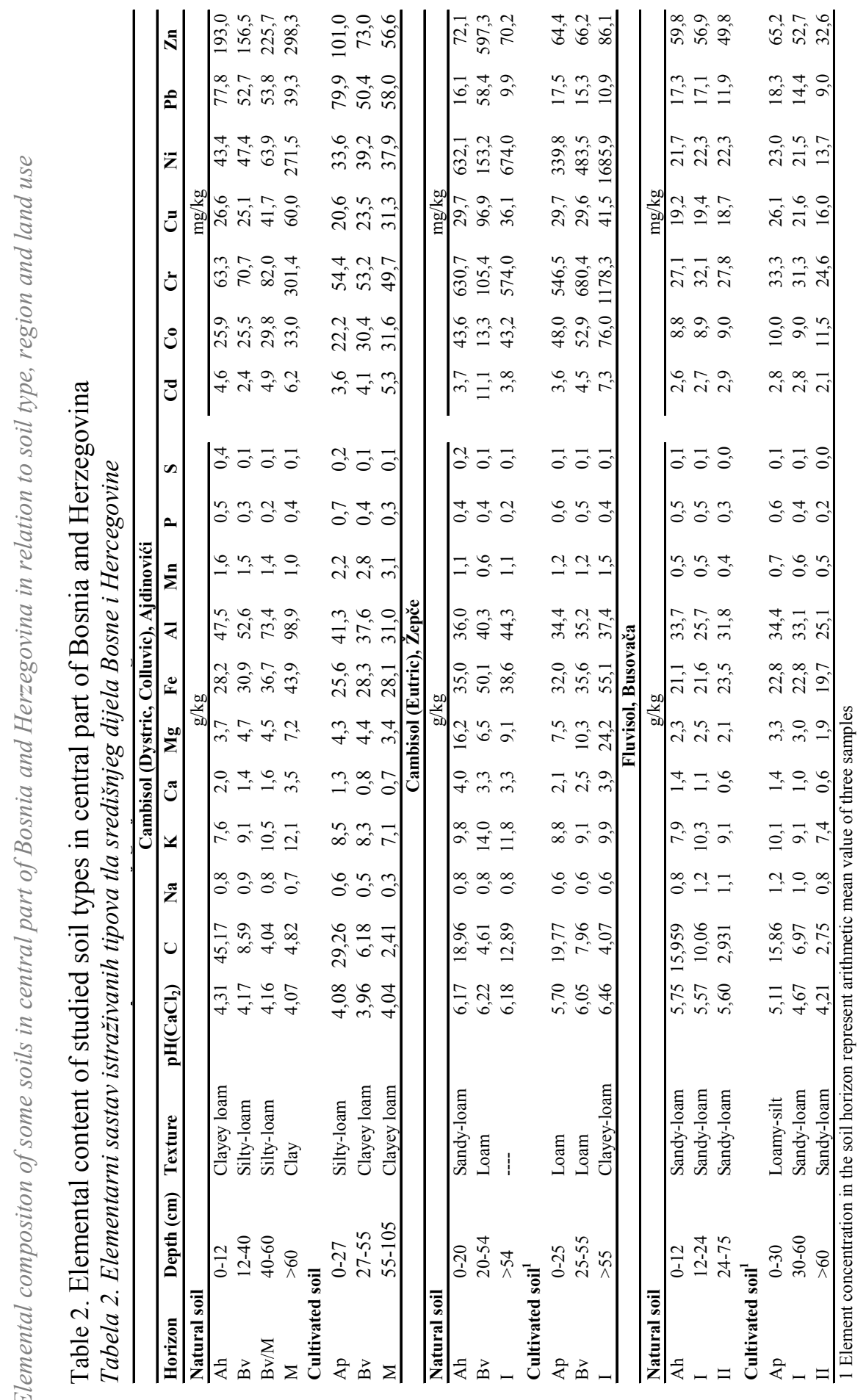


In addition to heavy metals content there were significantly higher amounts of $\mathrm{Cd}(Z=2.009, p<0.05, Z=1.738, p<0.05), \mathrm{Pb}(Z=2.882, p<0.01, Z=2.739, p<0.05)$ and $\mathrm{Zn}(Z=2.402, p<0.05, Z=2.191, p<0.01)$, which are found to be related to parent material (RAMOVIĆ, 1985).

Significantly higher values were noticed in $\operatorname{Mg}(Z=3.780, p<0.01, Z=3.824$, $p<0.01), \mathrm{Ni}(Z=2.882, p<0.01, Z=2.739, p<0.01)$ and $\mathrm{Cr}(Z=2.882, p<0.01, Z=2.739$, $p<0.01)$ concentrations in 0 to $30 \mathrm{~cm}$ of soil depth in Žepče compare to Ajdinovići and Busovača. High concentrations of $\mathrm{Mg}, \mathrm{Cd}, \mathrm{Co}, \mathrm{Cr}$ and $\mathrm{Ni}$ are considered to be closely related to chemical composition of peridotitic and serpentinitic rocks, which chemical content is dominantly composed of Si-oxides (38,4-42,9\%) and Mg-oxides (10,4-42,5\%) (PAMIĆ ET AL., 1966) and broadly known for it high Ni and Cr concentrations (CHENG ET AL., 2011). Average concentration of $\mathrm{Cr}$ and $\mathrm{Ni}$ for peridotitic rocks, reported by SCHEFFER AND SCHACHTSCHABEL (2002), are $1600 \mathrm{mg} / \mathrm{kg}$ and $2000 \mathrm{mg} / \mathrm{kg}$.

On the other hand, Busovača tended to have the highest concentrations of $\mathrm{Na}$ $(Z=3.956, p<0.01, Z=3.956, p<0.01)$ and $\mathrm{K}(Z=2.572, p<0.01, Z=2.638, p<0.01)$, compare to the soils in Ajdinovići and Žepče. Potassium concentrations are inevitably related to chemical content of muscovite and sericite which appear in the glacialalluvial parent material of Busovača site.

Tabela 3. Element concetrations at the depth $0-30 \mathrm{~cm}$ in relation to study site

Tabela 3. Elementarni sastav u sloju tla do dubine od $30 \mathrm{~cm}$ u odnosu na područje istraživanja

\begin{tabular}{|c|c|c|c|c|c|c|c|c|c|c|}
\hline Study site & Nb. & D.s. & \multicolumn{8}{|c|}{$\mathrm{g} / \mathrm{kg}$} \\
\hline \multirow[t]{2}{*}{ Ajdinovići } & 10 & Median & 0,72 & 9,14 & 2,07 & 4,32 & 33,07 & 58,07 & 2,03 & 0,57 \\
\hline & & Range & $0.5-0.9$ & $7.1-9.7$ & $0.8-5.5$ & $2.8-4.9$ & $25.1-48.8$ & $42.7-79.8$ & $1.6-3.5$ & $0.2-0.7$ \\
\hline \multirow[t]{2}{*}{ Žepče } & 10 & Median & 0,64 & 9,07 & 3,95 & 8,66 & 28,95 & 35,37 & 0,93 & 0,40 \\
\hline & & Range & $0.6-0.8$ & $8.3-10.4$ & $2.3-12.4$ & $6.4-19.3$ & $25.0-41.4$ & $31.0-44.1$ & $0.6-1.2$ & $0.3-0.6$ \\
\hline \multirow[t]{2}{*}{ Busovača } & 12 & Median & 1,23 & 11,52 & 4,57 & 4,67 & 25,88 & 50,56 & 0,75 & 0,53 \\
\hline & & Range & $0.9-2.0$ & $8.2-17.3$ & $1.1-12.3$ & $3.0-7.2$ & $22.3-52.9$ & $31.5-56.8$ & $0.4-1.2$ & $0.4-0.9$ \\
\hline$X^{2}$ & & & 22,475 & 9,470 & 5,988 & 20,279 & 1,252 & 13,314 & 21,008 & 5,245 \\
\hline$d f$ & & & 2 & 2 & 2 & 2 & 2 & 2 & 2 & 2 \\
\hline$p$ & & & ,000 & ,009 &, 050 &, 000 &, 535 &, 001 &, 000 &, 073 \\
\hline Study site & Nb. & D.s. & $\begin{array}{c}\mathbf{S}^{1} \\
\mathrm{~g} / \mathrm{kg}\end{array}$ & Cd & Co & $\mathrm{Cr}$ & $\begin{array}{l}\mathbf{C u} \\
\mathrm{mg} / \mathrm{kg}\end{array}$ & $\mathbf{N i}$ & $\mathbf{P b}$ & Zn \\
\hline \multirow[t]{2}{*}{ Ajdinovići } & 10 & Median & 0,30 & 3,85 & 20,65 & 64,50 & 21,45 & 36,15 & 74,90 & 107,45 \\
\hline & & Range & $0.3-0.6$ & $2.7-7.7$ & $17.6-36.3$ & $54.7-75.3$ & $17.6-62.3$ & $31.3-83.2$ & $58.7-157.8$ & $87.8-331.3$ \\
\hline \multirow[t]{2}{*}{ Žepče } & 10 & Median & 0,27 & 3,10 & 23,15 & 339,30 & 24,95 & 245,45 & 18,55 & 64,95 \\
\hline & & Range & $0.1-0.6$ & $2.8-3.8$ & $14.6-46.8$ & $185.5-607.3$ & $16.2-33.1$ & $123.1-391.1$ & $15.3-34.2$ & $55.9-101.5$ \\
\hline \multirow[t]{2}{*}{ Busovača } & 12 & Median & 0,17 & 3,15 & 10,05 & 43,60 & 24,85 & 24,25 & 16,85 & 67,60 \\
\hline & & Range & $0.1-0.4$ & $2.7-3.5$ & $8.7-10.9$ & $31.9-49.9$ & $20.3-30.3$ & $21.1-28.1$ & $13.5-20.0$ & 61.1-121.1 \\
\hline$X^{2}$ & & & 5,117 & 9,111 & 20,708 & 29,284 & 0,336 & 29,284 & 24,183 & 16,249 \\
\hline$d f$ & & & 2 & 2 & 2 & 2 & 2 & 2 & 2 & 2 \\
\hline$\underline{p}$ & & &, 077 & 0,011 & 0 & 0 & 0,845 & 0 & 0 & 0 \\
\hline
\end{tabular}

Elemental composition of soil in relation to land use - Elementarni sastav tla u odnosu na način korištenja

Table 4 shows medians and ranges of the element concentrations in natural and cultivated soil with a reference to the soil type. Analyses of the average element 
concentrations have shown no significant changes in relation to the land use for the most of elements observed, what so ever.

In forest nursery Ajdinovići significant deficiency occurred in the amounts of $\mathrm{Ca}$ in $0-10$ and $10-30 \mathrm{~cm}$ soil depth $(Z=1.265, p<0.05)$ and $\mathrm{S}$ in $0-10 \mathrm{~cm}(Z=1.265$, $p<0.05)$. Significantly higher amounts of $\mathrm{P}$, due to fertilizers application, were noticed in cultivated soil at the depths $0-10$ and $10-30 \mathrm{~cm}(Z=1.581, p<0.01)$.

Table 4. Element concentrations in 0-10 and $10-30 \mathrm{~cm}$ of the soil depth in relation to land-use Tabela 4. Elementarni sastav u prosječnim uzorcima na dubini od 0-10 i 10-30 cm u odnosu na način korišenja

\begin{tabular}{|c|c|c|c|c|c|c|c|c|c|c|}
\hline Site & Nb. D.s. & $\mathrm{Na}$ & $\mathbf{K}$ & $\mathrm{Ca}$ & $\mathrm{Mg}$ & $\mathrm{Fe}$ & Al & Mn & $\mathbf{P}$ & $\underline{S}$ \\
\hline Ajdinovići & & & & & & $\mathrm{g} / \mathrm{kg}$ & & & & \\
\hline \multirow[t]{2}{*}{ NS $0-10$} & $5 \mathrm{M}$ & 0,69 & 9,29 & 2,61 & 4,16 & 35,49 & 58,02 & 1,97 & 0,33 & 0,48 \\
\hline & Range & $0.5-0.8$ & $8.7-9.4$ & $1.8-5.8$ & $3.9-4.8$ & $26.5-46.5$ & $47.9-77.3$ & $1.5-2.4$ & $0.2-0.6$ & $0.3-0.7$ \\
\hline \multirow[t]{2}{*}{ NS $10-30$} & $5 \mathrm{M}$ & 0,76 & 8,95 & 1,24 & 4,44 & 37,67 & 61,36 & 1,88 & 0,33 & 0,36 \\
\hline & Range & $0.5-1.0$ & $8.8-10.0$ & $1.8-5.2$ & 4.1-4.9 & $26.2-51.1$ & $48.1-82.3$ & $1.6-2.8$ & $0.2-0.5$ & $0.3-0.6$ \\
\hline \multirow[t]{2}{*}{ CS $0-10$} & $5 \mathrm{M}$ & 0,76 & 8,95 & 1,24 & 4,44 & 28,46 & 46,51 & 2,21 & 0,68 & 0,29 \\
\hline & Range & $0.4-0.9$ & $6.4-9.3$ & $0.6-4.1$ & $2.4-4.5$ & $24.9-43.6$ & $42.4-71.0$ & $1.8-3.8$ & $0.6-0.7$ & $0.2-0.3$ \\
\hline \multirow[t]{2}{*}{ CS $10-30$} & $5 \mathrm{M}$ & 0,76 & 8,95 & 1,24 & 4,44 & 27,60 & 48,17 & 2,27 & 0,65 & 0,29 \\
\hline & Range & $0.6-0.8$ & 7.8-9.4 & $1.0-6.1$ & $3.1-4.5$ & $25.0-43.2$ & $43.0-71.5$ & $1.7-3.3$ & $0.6-0.7$ & $0.2-0.3$ \\
\hline \multicolumn{11}{|l|}{ Žepče } \\
\hline \multirow[t]{2}{*}{ NS $0-10$} & $5 \mathrm{M}$ & 0,58 & 8,98 & 4,29 & 9,24 & 28,45 & 34,98 & 0,92 & 0,41 & 0,39 \\
\hline & Range & $0.6-0.7$ & $8.2-9.7$ & $3.4-12.5$ & $8.3-18.3$ & $26.5-40.1$ & $30.6-44.1$ & $0.77-1.2$ & $0.3-0.5$ & $0.3-0.6$ \\
\hline \multirow[t]{2}{*}{ NS $10-30$} & $5 \mathrm{M}$ & 0,5906 & 8,9701 & 3,917 & 9,237 & 31,88 & 34,02 & 0,96 & 0,39 & 0,28 \\
\hline & Range & $0.6-0.7$ & $8.3-9.4$ & $3.1-12.3$ & $9.1-20.3$ & $27.6-42.7$ & $31.5-44.2$ & $0.9-1.2$ & $0.3-0.5$ & $0.2-0.5$ \\
\hline \multirow[t]{2}{*}{ CS $0-10$} & $5 \mathrm{M}$ & 0,70 & 9,27 & 3,06 & 7,75 & 29,44 & 35,97 & 0,88 & 0,44 & 0,20 \\
\hline & Range & $0.6-0.9$ & $7.9-10.8$ & $1.9-6.0$ & $6.2-8.8$ & $23.3-37.2$ & $34.2-39.1$ & $0.5-1.1$ & $0.4-0.6$ & $0.1-0.3$ \\
\hline \multirow[t]{2}{*}{ CS $10-30$} & $5 \mathrm{M}$ & 0,69 & 9,26 & 3,11 & 6,90 & 26,83 & 35,58 & 0,86 & 0,38 & 0,19 \\
\hline & Range & $0.6-0.7$ & $7.8-10.3$ & $1.9-4.8$ & $6.3-8.4$ & $23.3-37.2$ & $34.0-37.9$ & $0.6-1.2$ & $0.4-0.6$ & $0.1-0.3$ \\
\hline \multicolumn{2}{|l|}{ Busovača } & & & & & $\mathrm{g} / \mathrm{kg}$ & & & & \\
\hline \multirow[t]{2}{*}{ NS $0-10$} & $8 \mathrm{M}$ & 1,24 & 11,42 & 11,02 & 6,07 & 57,66 & 60,55 & 1,11 & 0,49 & 0,40 \\
\hline & Range & $1.2-1.3$ & $10.9-11.9$ & $3.3-12.6$ & $3.3-7.5$ & $21.4-60.1$ & $28.2-61.5$ & $0.6-1.2$ & $0.4-0.9$ & $0.3-0.4$ \\
\hline \multirow[t]{2}{*}{ NS 10-30 } & $8 \mathrm{M}$ & 1,22 & 11,68 & 10,07 & 5,97 & 57,71 & 59,45 & 1,09 & 0,48 & 0,31 \\
\hline & Range & $1.2-1.2$ & $10.7-11.8$ & $2.5-12.0$ & $2.9-7.0$ & $21.3-61.8$ & $34.3-61.8$ & $0.5-1.2$ & $0.5-0.8$ & $0.2-0.3$ \\
\hline \multirow[t]{2}{*}{ CS $0-10$} & $4 \mathrm{M}$ & 1,33 & 11,87 & 2,38 & 4,14 & 24,35 & 39,94 & 0,55 & 0,49 & 0,16 \\
\hline & Range & $0.9-2.0$ & $7.9-17.0$ & $1.2-6.1$ & $3.1-6.1$ & $24.4-24.4$ & $38.0-37.1$ & $0.4-0.8$ & $0.4-0.8$ & $0.1-0.5$ \\
\hline \multirow[t]{2}{*}{ CS $10-30$} & $4 \mathrm{M}$ & 1,29 & 11,46 & 2,28 & 4,30 & 24,94 & 38,14 & 0,54 & 0,49 & 0,15 \\
\hline & Range & $0.9-2.0$ & $8.5-17.6$ & $1.1-6.2$ & $2.9-6.2$ & $22.0-26.9$ & $30.5-58.0$ & $0.4-0.7$ & $0.4-0.8$ & $0.1-0.3$ \\
\hline
\end{tabular}

Note: Nb.-number, D.s.-descriptive statistic.

Soil cultivation has significantly affected lower concentrations of extractable $\mathrm{Mg}$ and $\mathrm{S}$ in Žepče $(Z=1.265, p<0.05, Z=1.581, p<0.01, Z=1.265, p<0.05, Z=1.265$, $p<0.05)$ compare to natural soils at the depths of $0-10$ and $10-30 \mathrm{~cm}$.

Also, significantly higher amounts of $\mathrm{S}$ were detected in Busovača $(\mathrm{Z}=1.429$, $p<0.05)$, whereas it could be argued that organic matter plays an important role for $\mathrm{S}$ accumulation in surface soil horizons (BRADY, 1990). 
Accordingly, forest seedling production significantly effects organically bounded $\mathrm{S}$ at the depths $0-10$ and $10-30 \mathrm{~cm}$, compare to corresponding natural soils. Accumulation of $\mathrm{P}$ in the top $0-10$ and $10-30 \mathrm{~cm}$ depth is considered to be influenced by fertilizers application (WAL ET AL., 2007).

Extensive production such as forest seedlings production does not result in easily conspicuous secondary nutrients deficiencies, although significant decrease in $\mathrm{Ca}$ and $\mathrm{Mg}$ in Ajdinovići and Žepče occurred.

\section{Elemental composition of investigated soils in central part of Bosnia and Herzegovina - Elementarni sastav tala središnjeg dijela BiH}

Table 5. shows the descriptive statistics, i.e., arithmetic mean, geometric mean, median and range of 16 elements for analyzed soil samples at the depth 0 to 30 $\mathrm{cm}$.

Table 5. Descriptive statistic parameters for 16 elements in 0 to $30 \mathrm{~cm}$ soil depth in central part od B\&H

Tabela 5. Pregled deskriptivno statističkih parametara 16 analiziranih elemenata tla na dubini od 0-30 cm u središnjem dijelu $B \& H$

\begin{tabular}{|c|c|c|c|c|c|c|c|c|c|c|}
\hline \multirow[t]{3}{*}{ Element $^{1}$} & \multirow[b]{3}{*}{$\mathrm{N}$} & \multirow{2}{*}{\multicolumn{4}{|c|}{$\begin{array}{c}\text { This report } \\
\text { (HNO }_{3} \text { pressure digestion procedure) } \\
\text { pseudo-total concentrations }\end{array}$}} & \multirow[t]{2}{*}{$\begin{array}{c}\text { Rose et al., } \\
1979 \\
\end{array}$} & \multirow{2}{*}{ 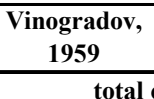 } & $\begin{array}{c}\text { Jackson, } \\
1964 \\
\end{array}$ & $\begin{array}{c}\text { Brooks, } \\
1972 \\
\end{array}$ & \multirow[t]{2}{*}{$\begin{array}{c}\text { Bowen, } \\
1979 \\
\end{array}$} \\
\hline & & & & & & & & concentratio & & \\
\hline & & $\mu^{2}$ & geo. mean ${ }^{3}$ & $\mathrm{M}^{4}$ & range & $\mathrm{M}^{4}$ or range & $\mu^{2}$ & $\mu^{2}$ or range & $\mu^{2}$ or range & $\mathrm{M}^{4}$ \\
\hline $\mathbf{N a}$ & 34 & 0,92 & 0,85 & 0,76 & $0.47-1.96$ & --- & 6,3 & ---- & ---- & 5 \\
\hline $\mathbf{K}$ & 34 & 10,20 & 9,97 & 9,30 & $7.11-17.3$ & 11,0 & 13,6 & $0.4-28.0$ & ---- & 14 \\
\hline $\mathrm{Ca}$ & 34 & 4,38 & 3,41 & 3,54 & $0.80-12.4$ & ---- & 13,7 & 7,0 & ---- & 15 \\
\hline Mg & 34 & 6,05 & 5,53 & 5,28 & $2.76-19.3$ & ---- & 6,3 & $<6.0$ & ---- & 5 \\
\hline $\mathbf{F e}$ & 34 & 32,90 & 31,67 & 27,88 & $22.3-52.9$ & 21,0 & 38,0 & $7.0-42.0$ & $10.0-50.0$ & 40 \\
\hline Al & 34 & 46,43 & 44,84 & 43,71 & $31.1-79.8$ & ---- & 71,3 & $10.0-60.0$ & ---- & 71 \\
\hline Mn & 34 & 1,24 & 1,07 & 0,98 & $0.43-3.52$ & 0,32 & 0,85 & ---- & 0,85 & 1 \\
\hline $\mathbf{P}$ & 34 & 0,49 & 0,47 & 0,50 & $0.17-0.78$ & 0,30 & 0,8 & 0,5 & ---- & 0,8 \\
\hline $\mathbf{S}$ & 34 & 0,29 & 0,26 & 0,27 & $0.11-0.63$ & $0.1-2.0$ & 0,85 & ---- & ---- & --- \\
\hline Cd & 17 & 3,60 & 3,30 & 3,46 & $2.70-7.70$ & ---- & ---- & ---- & ---- & --- \\
\hline Co & 17 & 20,7 & 18,9 & 18,4 & $8.70-46.8$ & ---- & 8 & ---- & 10,0 & --- \\
\hline $\mathrm{Cr}$ & 17 & 158,1 & 67,3 & 99,5 & $31.9-607.3$ & 6,3 & 200 & ---- & 200 & --- \\
\hline $\mathrm{Cu}$ & 17 & 26,0 & 24,3 & 24,7 & $16.2-62.3$ & 15,0 & 20,0 & 20,0 & 20,0 & 30,0 \\
\hline $\mathbf{N i}$ & 17 & 110,7 & 36,7 & 65,1 & $21.1-391.1$ & 17,0 & 40,0 & ---- & 40,0 & 50,0 \\
\hline $\mathbf{P b}$ & 17 & 41,8 & 19,8 & 30,6 & $13.5-157.8$ & 17,0 & ---- & ---- & 10,0 & --- \\
\hline Zn & 17 & 105,6 & 71,8 & 90,7 & $55.9-331.3$ & 36,0 & 50,0 & ---- & 50,0 & 90,0 \\
\hline
\end{tabular}

${ }^{1}$ Element concentrations of natrium $(\mathrm{Na})$, potassium $(\mathrm{K})$, calcium $(\mathrm{Ca})$, magnesium $(\mathrm{Mg})$, iron $(\mathrm{Fe})$, aluminum $(\mathrm{Al})$, manganese $(\mathrm{Mn})$, phosphorous $(\mathrm{P})$ and sulfur $(\mathrm{S})$ are given in $\mathrm{g} / \mathrm{kg}$ and for cadmium $(\mathrm{Cd})$, cobalt $(\mathrm{Co})$, chromium $(\mathrm{Cr})$, copper $(\mathrm{Cu})$, nickel $(\mathrm{Ni})$, lead $(\mathrm{Pb})$ and zinc $(\mathrm{Zn})$ in $\mathrm{mg} / \mathrm{kg}$.

${ }^{2} \mu$-arithmetic mean

${ }^{3}$ geo. mean-geometric mean

${ }^{4}$ median-M 
The histograms indicated distribution similar to normal for $\mathrm{P}, \mathrm{S}$ and $\mathrm{Al}$ concentrations, whereas arithmetic mean and median are considered as representative values. However $\mathrm{Na}, \mathrm{K}, \mathrm{Ca}, \mathrm{Mg}$ and micro-elements $\mathrm{Fe}, \mathrm{Mn}, \mathrm{Cd}, \mathrm{Co}, \mathrm{Cr}, \mathrm{Cu}, \mathrm{Ni}, \mathrm{Pb}$ and $\mathrm{Zn}$ showed the distribution similar to logarithmic normal distribution, whereas median and geometrical curve could be considered better representative values (YANAI ET AL., 2012).

Compare to some of the reported values in the United States (ROSE ET AL., 1979, JACKSON, 1964, BROOKS, 1972), Russia (VINOGRADOV, 1959) and soils of the world (BOWEN, 1979) the results of this research were approximately within the normal ranges and lower values for some elements can be explained by the differences in the extraction procedures. Significantly lower concentrations of $\mathrm{Na}$ and $\mathrm{Ca}$, could be explained also by the deficiency of salty and calcareous soils in the analyzed sample. In addition calculations of average values were made on fewer soil types in central parts of the country. High concentrations of $\mathrm{Pb}, \mathrm{Zn}, \mathrm{Cr}$ and $\mathrm{Ni}$ are probably the result of geochemical content of ultramafic parent material in Ajdinovići and Žepče (RosE ET AL., 1979). Values of Cd were not present in reports of other authors, but soils at all three investigated sites have significant rate of $\mathrm{Cd}$ contamination, judging by the value of a minimum concentration given by Law on Agricultural Land of Bosnia and Herzegovina (Table 5).

\section{CONCLUSIONS - Zaključci}

Element concentrations are reported based on 34 soil samples from the depth 0-30 cm. This data give approximate information on possible concentrations of 16 extractable elements for three different sites in central part of Bosnia and Herzegovina. Vertical distribution of, i.e., $\mathrm{Na}, \mathrm{K}, \mathrm{Ca}, \mathrm{Mg}, \mathrm{Fe}, \mathrm{Mn}, \mathrm{P}, \mathrm{S}, \mathrm{Al}, \mathrm{Cd}, \mathrm{Co}, \mathrm{Cu}, \mathrm{Cr}, \mathrm{Ni}, \mathrm{Pb}$, $\mathrm{Zn}$, is determined in three rather common soil types in this region. Carbon, $\mathrm{P}, \mathrm{S}, \mathrm{Ca}$, and $\mathrm{Mg}$ had higher rate of alternation in the soil profiles, while $\mathrm{Na}, \mathrm{K}$ and microelements were described with a lower rate of vertical alternation on the profile scale. There was a significant influence of site characteristics, especially parent material on elemental composition of soil. Whereas, potentially toxic concentrations of some microelements found in soils of Ajdinovići, Žepče and Busovača are regarded as geogenic. Land-use significantly influenced $S$ concentrations at all three investigated sites and in Ajdinovići and Žepče $\mathrm{Ca}$ and $\mathrm{Mg}$ depletion occurred in cultivated soils.

\section{REFERENCES - Literatura}

AdRIANO, D.C. (1986): Trace elements in the Terrestrial Environment, Springer-Verlag Inc., New York.

Benavides, M.P., Gallego, S.M., Tomaro, M.L. (2005): Cadmium toxicity in plants, Braz. J. Plant. Physiol. 17(1), 21-34. 
Bowen, H.J.M. (1979): Environmental Chemistry of the Elements. Academic Press Inc. Ltd., London.

Brady, N. (1990): The Nature and Properties of Soils. $10^{\text {th }}$-ed. New York.

BROOKS, R.R. (1972): Geobotany and biogeochemistry in mineral exploration: New York, Harper and Row.

Cheng, C., Jien, S., IIZukA, Y., Heng, T., Chang, Y., Hseu, Z. (2011): Pedogenic Chromium and Nickel Partitioninig in Serpentine Soils along a Toposequence. Soil. Sci. Soc. Amer. Journal, 75-2.

ĆIRIĆ, M. (1986): Pedologija. Svjetlost, OOUR Zavod za udžbenike i nastavna sredstva, Sarajevo.

FAO (2006): Guidelines for soil description $4^{\text {th }}$-ed. Rome.

GOLETIĆ, Š. (1999): Istraživanje teških metala u tlu i povrću zeničke regije. Zbornik radova, Filozof. Fak. Univerziteta u Tuzli. 1(1), 149-156.

IUSS WORKING GROUP WRB, (2006): World reference base for soil resources 2006. World Soil Resources Reports 103. FAO, Rome.

IVETIĆ, B. (1987): Kontaminacija zemljišta teškim metalima, sumporom i pesticidima u urbanim područjima grada Sarajeva. Studija. Zavod za agropedologiju, Sarajevo.

IVetić, B., Resulović, H., Vukorep, I., Pehar, J., Čarkić, T. (1987): Bilans teških metala u tlu, njihov odnos u tlu i biljci i uticaj na biljnu proizvodnju na području opštine Zenica. Izvještaj za 1987. god., Zavod za agropedologiju, Sarajevo.

JACKSON, M.L. (1964): Chemical composition of soil in Bear, F.E., ed., Chemistry of soil, $2^{\text {d}}$-ed. New York.

Kabata-Pendias, A. \& Krakowiak, A. (1995): Soil parameters as a base for the calculation of background heavy metal status, Int. Conf. Heavy Metals in the Environment, Wilkens, R.-D., Förstnwe, U., and Knöchel, A.,1-ed.

Kabata-Pendias, A. \& Pendias, H. (2001): Trace elements in Soils and Plants.- 3rd ed. New York.

Lee, B.D., CARTeR, B.J., BAStA, N.T., Weaver, B. (1997): Factors influencing heavy metal distribution in six Oklahoma benchmark soils, Soil. Sci. Soc. Am. J., 61218.

PAmić, J., SunARIĆ-PAmić, O., KaPeler, I., OluJIĆ, J. (1966): Tumač za list Zavidovići Osnovne geološke karte SFRJ, MJ 1:100000.

PetKović, K. (1961): La carte tectonique de la RPF de Yugoslavie. Glas SANU, 149, Odeljenje prirodno-matematičkih nauka, Beograd, 22, 129-144.

PRASAD, R. \& POWER, J. (1997): Soil fertility management for sustainable agriculture. New York. 
RAMOVIĆ, M., (1984): Geološke i geohemijske karakteristike područja Bakića, Veovače, Budoželja, Elaborat "Ekosistemi sa visokom koncentracijom teških metala". PMF - Sarajevo.

ROSE, A.W, HAWKES, H.E., WEBB, J.S., (1979): Geochemistry in mineral exploration 2d-ed. London, Academy Press.

SCHEFfER, F. \& SCHACHTSCHABEL, P. (2002): Lehrbuch der Bödenkunde. 15 Auflage. Akademisches Verlag, Berlin.

ShACKLETTE, H. T. \& BoeRngen, J. G., (1984): Element concentration in soils and other surficial materials of the conterminous United States. United States Government printing office, Washington.

SIDDIQUI, S. \& KHATTAK, R.A. (2012): Heavy metals distribution in the soil of Peshawar valley, Northern-Pakistan. Scientific Research and Essays, 7(5), 544-552.

StRAJIN, V., MOJIĆEVIć, M., PAmIĆ, J., SUNARIć-PAMIĆ, O., VelJKoVIĆ, D., ĐoreEVIć, D. (1978): Osnovna geološka karta SFRJ, MJ 1:100.000. Geoinženjering, OOUR Institut za geologiju, Sarajevo.

SunARIĆ-PAmić, O., PAmIĆ, J., KAPELAR, J., OluJić, J., ZeC, F. (1966): Osnovna geološka karta 1:100.000. SFRJ, Institut za geološka istraživanja, Sarajevo.

ToKIĆ, S. (1983): Geneza i glavne odlike kvartarnih naslaga Bosne i Hercegovine. Geološki glasnik 28, Sarajevo.

URE, A.M. (1996): Single extraction schemes for soil analysis and related applications. The Science of the Total Environment, 178, 3-10.

VINOGRADOV, A.P. (1959): The geochemistry of rare and dispersed chemical elements in soil, 2d-ed., revised and enlarged, New York.

WAL der VAN, A., Boer de W., LubBers, I.M., VAN VeEN, J.A. (2007): Concentration and vertical distribution of total soil phosphorus in relation to time of abandonment of arable fields. Nutr. Cycl. Agroecosystem, 79, 73-79.

WolfF, W.R., BARTiz, R., HenNIG, P. (1996): Deutscher Waldbodenbericht. Bundesforschungsanstalt für Forst- und Holzwirtschft, Institut für Forstekölogie und Walderfassung, Eberswalde Bund-Länder-Arbeitsgruppe BZE.

YANAI, J., OKADA, T., YAMADA, H. (2012): Elemental composition of agricultural soils in Japan in relation to soil type, land use and region. Soil science and plant nutrition, $58,1-10$.

ŽIVANOVIĆ, M., SofILJ, J., MILOJEVIĆ, R. (1967): Osnovna geološka karta SFRJ, Sekcija Zenica MJ 1:100.000. Institut za geološka istraživanja-Sarajevo.

\section{Sažetak}

Sadržaj pojedinih makro i mikro-elemenata u površinskim i podpovršinskim slojevima tla je u najvećoj mjeri određen geološkim i pedološkim faktorima. Pored 
navedenih faktora, čovjek različitim aktivnostima može $u$ znatnoj mjeri uticati na promjene u akumulaciji i distribuciji pojedinih elemenata, među kojima su sa ekološkog stanovišta najznačajnije promjene u distribuciji onih elemenata koji su potencijalno toksični za biljke, životinje i čovjeka.

Analize elementarnog sastava tla $u$ Bosni i Hercegovini su provođene pretežno iz ekonomski opravdanih razloga, za hidrogeološke potrebe, eksploataciju mineralnih sirovina $i$ sporadično radi otkrivanja toksičnih koncentracija u poljoprivrednim i urbanim tlima.

S obzirom na značaj elementarnog sastava tla za ocjenu produktivnosti i kvaliteta terestričnih ekosistema ciljevi rada su bili da se: 1) odredi vertikalna distribucija macro- i mikro-elemenata u tlu u odnosu na tip tla; 2) odnos između sadržaja elemenata, načina korištenja i područja istraživanja i 3) utvrdi aproksimativni sadržaj pojedinih elemenata u površinskom sloju tla u središnjem dijelu Bosne i Hercegovine.

U tu svrhu su analizirani uzorci (31) iz pedoloških profila i prosječni uzorci (64) uzeti sondom iz dubina od 0-10 i od 10-30 cm. Sadržaj 16 elemenata, među kojima su $\mathrm{Na}, \mathrm{K}, \mathrm{Ca}, \mathrm{Mg}, \mathrm{Fe}, \mathrm{Al}, \mathrm{Mn}, \mathrm{S}, \mathrm{P}, \mathrm{Cd}, \mathrm{Co}, \mathrm{Cr}, \mathrm{Cu}, \mathrm{Ni}, \mathrm{Pb}$ i $\mathrm{Zn}$, je određen HNO3 digestijom pod pritiskom, dok je sadržaj $\mathrm{C}$ određen na elementarnom analizatoru.

Rezultati istraživanja pružaju uvid u elementarni sastav tri vrlo česta tipa tla, distričnog kambisola, eutričnog kambisola i beskarbonatno-silikatnog fluvisola $\mathrm{u}$ središnjem dijelu Bosne i Hercegovine. Vrijednosti C, P, S, Ca i $\mathrm{Mg}$ su najpromjenjivije u odnosu na dubinu tla, dok su vrijednosti $\mathrm{Na}$ i $\mathrm{K}$, te mikroelemenata uglavnom ujednačene u vertikalnom smislu.

Matični supstrat istraživanih područja je imao nesumnjivo najjači uticaj na elementarni sastav tala, a potencijalno toksične koncetracije $\mathrm{Cd}$ na sve tri lokacije, $\mathrm{Pb}$, $\mathrm{Mn}, \mathrm{Zn}$ na području Ajdinovića, te Ni i Cr na području Žepča se smatraju geogenim.

Efekti načina korištenja zemljišta u svrhu rasadničke proizvodnje u šumarstvu, ispoljeni u odnosu na prirodna tla, su povećanje vrijednosti $\mathrm{P}$, smanjenje vrijednosti $\mathrm{C}$ i S na sva tri lokaliteta, kao i smanjenje vrijednosti Ca i Mg na području Ajdinovića i Žepča. 